\title{
The effects of intravenous infusions of triglycerides on the composition of milk fat in the sow
}

\author{
By R. C. WITTER, J. SPINCER, J. A. F. ROOK AND K. G. TOWERS \\ Division of Agricultural Chemistry, School of Agricultural Sciences \\ The University of Leeds
}

(Received 20 fune 1969-Accepted 12 August 1969)

\begin{abstract}
I. Emulsions with egg phosphatides of nine synthetic triglycerides (tributyrin, tricaprylin, tripelargonin, tricaprin, trilaurin, trimyristin, tripalmitin, triisostearin, triolein) and of rapeseed oil and a proprietary emulsion of cottonseed oil were given as continuous infusions into the jugular vein of lactating sows. The effects of the infusions on the concentration and composition of blood plasma lipids and on the composition of milk fat were determined.

2. The infusions did not affect the concentrations in blood plasma of cholesterol, phospholipid or cholesterol esters, but there was a tendency for the concentration of plasma triglycerides to be increased which was most pronounced for the infusions of longer-chain triglycerides. The fatty acid composition of the plasma triglycerides was not altered by the infusion of tributyrin, except that there was an increase in the content of oleic and a decrease in that of linoleic acid. With other infusions the composition of the plasma triglycerides was altered towards that of the infused material and the effect was more marked for the longer-chain triglycerides, with the exception of triisostearin.

3. The changes in the composition of the milk fat reflected those in the composition of plasma triglycerides, with two exceptions. The infusion of tripalmitin was associated with an increase not only in the palmitic acid content of milk fat but also in the palmitoleic acid content. Also, the changes in the content in milk fat of eicosenoic acid and, more especially of erucic acid during the infusion of rapeseed oil were much less than the corresponding changes in the plasma triglycerides.
\end{abstract}

Studies of arteriovenous differences across the mammary glands of lactating sows (Linzell, Mepham, Annison \& West, 1969; Spincer, Rook \& Towers, r969) have demonstrated an uptake of triglyceride fatty acids, which are incorporated largely into the triglycerides of milk fat (J. Spincer \& J. A. F. Rook, unpublished). The fatty acids principally involved are palmitic, stearic and oleic, the major fatty acids of the plasma triglycerides. The present experiments were undertaken to study the extent to which these and other fatty acids are transferred to milk fat when infused as triglycerides into the blood plasma.

Pharmacological and toxicological side-effects have been reported in a number of animal species following the infusion of vegetable oils in combination with a range of emulsifiers, but Schuberth \& Wretlind (196r) found emulsions of soya-bean oil with egg phosphatides to be free of such effects. Emulsions with egg phosphatides of tripropionin, tricaproin, tricaprylin, tripelargonin, tricaprin, trilaurin and triolein (Storry, Tuckley \& Hall, r969) and of cottonseed oil (Tove \& Mochrie, 1963; Storry \& Rook, 1964) have been successfully infused into lactating cows without clinical signs of distress. Egg phosphatides were therefore chosen as emulsifiers for the present work. 


\section{EXPERIMENTAL}

Animals and their management. Lactating Wessex/Landrace/Large White sows with piglets were taken as required from the University herd. Sows were confined in a holding crate and piglets to a separate pen. Suckling was permitted at $\mathrm{I} \cdot 5 \mathrm{~h}$ intervals. Meal $(5 \cdot 5 \mathrm{~kg} / \mathrm{head}$ per day) was offered to the sows twice daily and there was free access to water. Piglets had continuous access to creep feed and to water.

Experimental details. Emulsions of triglycerides rich in butyric, caprylic, pelargonic, capric, lauric, myristic, palmitic, isostearic or oleic acids and of rapeseed oil and a proprietary preparation of cottonseed oil (Intralipid; Vitrum, Stockholm, Sweden) were infused, through a cannula inserted in an ear vein, into each of two lactating sows (except for triisostearin, which was infused into one sow only) during the $5^{\text {th }}$ or 6th week of lactation. One 1. of emulsion was infused; the rate of infusion was approximately $40 \mathrm{ml} / \mathrm{h}$, except in the second of the experiments, in which tricaprylin, tripelargonin, tricaprin and rapeseed oil were infused, when the rate was increased to approximately $60 \mathrm{ml} / \mathrm{h}$ as little change in milk fat composition was detected at the lower rate. The emulsions were infused at a constant rate by means of a micropump (F. A. Hughes Ltd, Longmead, Epsom). Emulsions of triglycerides with meltingpoints above room temperature were maintained at $70^{\circ}$ and the line carrying the emulsion from the reservoir to the sow was held at about the same temperature by means of a water jacket.

Samples of coccygeal blood and of milk were taken at $6 \mathrm{~h}$ intervals throughout the infusion period and on three occasions during a preliminary control period. Milk was removed manually from a number of teats after the injection of oxytocin ( 1 i.u.) into a catheter inserted in an ear vein in the ear not used for infusion.

Preparation of emulsions. Tributyrin, tricaprylin, tripelargonin, tricaprin, trilaurin, trimyristin, and triolein were of 'Practical' grade (Fluka, A. G., Switzerland). The tripalmitin was specially prepared to contain $90 \%$ (w/w of the total fatty acids) palmitic acid, and triisostearin was synthesized from isostearic acid via the acid chloride. Emulsions were prepared by a modification of the method of Zeringue, Brown \& Singleton (1964). The composition (w/v) was: triglycerides, $20 \%$; egg phosphatides, $\mathrm{I} \cdot 2 \%$; glycerol solution $(2.5 \%, \mathrm{v} / \mathrm{v}) 78.8 \%$, except with trimyristin, tripalmitin and triisostearin the concentration of phosphatides was doubled, and with tripalmitin and triisostearin a 10\% emulsion was prepared.

The glycerol solution and triglycerides were heated separately to a temperature of $60-70^{\circ}$. Freshly prepared egg phosphatides (Singleton, Gray, Brown \& White, I965), dissolved in a minimum of warm chloroform, were added to the warm triglycerides, the mixture was transferred to a rotary evaporator and the solvent removed in vacuo under nitrogen at $50^{\circ}$. The triglyceride-phosphatide mixture and the glycerol solution were blended for $2 \mathrm{~min}$ and the resulting coarse emulsion was adjusted to $\mathrm{pH} 6.8$ by the addition of $0.1 \mathrm{~N}-\mathrm{NaOH}$. The mixture was transferred to a Q.P. Blue Calf homogenizer (Ormerod Engineers Ltd, Rochdale) previously warmed to $70^{\circ}$ by recycling hot water, and homogenization achieved by circulating the mixture for $45 \mathrm{~min}$ at an applied pressure of $\mathrm{I} 200 \mathrm{lb} / \mathrm{in}^{2}$ in an atmosphere of nitrogen. The $\mathrm{pH}$ was 
maintained at 6.8 by the addition of $0 . \mathrm{I} \mathrm{N}-\mathrm{NaOH}$. With triglycerides of high meltingpoint, the emulsion was removed at $15 \mathrm{~min}$ intervals and rewarmed to $70^{\circ}$. Emulsions were stored at $4^{\circ}$ under nitrogen and used for infusion the following day. Emulsions prepared in this way had a majority of fat particles with a diameter of less than I $\mu \mathrm{m}$.

Methods of analysis. Blood-plasma and milk lipids were extracted by the method of Folch, Lees \& Stanley (1957). Plasma lipids were separated into phospholipid, free fatty acid, cholesterol, triglyceride and cholesterol ester fractions by thin-layer chromatography on silicic acid (Freeman \& West, 1966), and the lipid fractions were measured by the method of Amenta (1964). The same procedure was used for the fractionation of plasma lipid classes before their analysis for fatty acid composition. The plates were sprayed with Ultraphor (Badische Anilin und Soda Fabrik A.G., Ludwigshafen-am-Rhein, Germany) and dried at $50^{\circ}$. The lipid bands were detected under u.v. light, lipid-containing zones of silica were individually scraped off the plate and the lipids eluted with chloroform-methanol $(2: \mathrm{I}, \mathrm{v} / \mathrm{v})$.

Milk lipids and plasma triglycerides, cholesterol esters and phospholipids were transesterified by using methanol-boron trifluoride in $\mathrm{H}_{2} \mathrm{SO}_{4}$ (Metcalfe \& Schmidt, I96I). The methyl esters were separated on a column of $\mathrm{I}, 4$-butanediol succinate polyester $(8 \%, w / w)$ on acid-washed Chromosorb W (80-100 mesh size) (Perkin Elmer Ltd, Beaconsfield, Bucks) in a Pye Model 104 gas chromatograph (W. G. Pye \& Co. Ltd, Cambridge). The temperature programme was $5 \mathrm{~min}$ at $50^{\circ}$ followed by a temperature increase of $16^{\circ} / \mathrm{min}$ to a final temperature of $220^{\circ}$.

\section{RESULTS}

Fatty acid composition of emulsions (Table $\mathrm{I}$ )

The tributyrin and tricaprylin used in the preparation of emulsions were pure. The other synthetic triglycerides contained between 75 and $98 \%$ of the theoretical content of the major acid. The main fatty acid impurities were: caprylic, capric, palmitic and oleic acids in tripelargonin; lauric acid in tricaprin; myristic acid in trilaurin; palmitic acid in trimyristin; stearic and oleic acids in tripalmitin; palmitic and oleic acids in triisostearin; and palmitic, palmitoleic, stearic and linoleic acids

\section{Table I. Fatty acid* composition $(g / 100 \mathrm{~g})$ of infused triglycerides}

\begin{tabular}{|c|c|c|c|c|c|c|c|c|c|c|c|c|c|c|c|}
\hline Emulsion & $4: 0$ & $6: 0$ & $8: 0$ & $9: 0$ & $10: 0$ & $12: 0$ & $x 4: 0$ & I6:0 & I6:I & $18: 0$ & I8: I & $18: 2$ & $18: 3$ & 20: 1 & $22: 1$ \\
\hline Tributyrin & $100 \cdot 0$ & - & - & - & - & - & - & - & - & 一 & - & - & - & - & 一 \\
\hline Tricaprylin & - & 一 & 100.0 & - & - & - & - & 一 & - & - & - & - & - & - & - \\
\hline Tripelargonin & - & tr & $x \cdot 7$ & 93.9 & $x \cdot 6$ & $\operatorname{tr}$ & $\operatorname{tr}$ & $r \cdot 6$ & - & $\operatorname{tr}$ & $I \cdot 2$ & - & - & - & 一 \\
\hline Tricaprin & - & - & - & - & 78.9 & $2 I \cdot I$ & - & - & - & - & - & - & - & - & 一 \\
\hline Trilaurin & 一 & - & - & - & - & $94 \cdot 6$ & $5 \cdot 4$ & - & - & - & - & - & - & 一 & 一 \\
\hline Trimyristin & - & - & - & - & 一 & tr & $97 \cdot 8$ & $2 \cdot 2$ & - & - & - & - & - & - & 一 \\
\hline Tripalmitin & - & - & 一 & - & - & 一 & $\operatorname{tr}$ & $90 \cdot 0$ & - & 49 & $5^{-1}$ & 一 & 一 & - & 一 \\
\hline Triisostearin & - & - & - & - & - & $\operatorname{tr}$ & $\operatorname{tr}$ & 3.9 & - & $84 \cdot 8$ & $9 \cdot 3$ & $2 \cdot 0$ & - & 一 & - \\
\hline Triolein & - & -. & - & - & - & - & tr & $2 \cdot I$ & 3.5 & $3 \cdot 8$ & $87 \cdot 4$ & $3 \cdot 2$ & - & - & - \\
\hline Intralipid & - & - & - & - & 一 & - & $2 \cdot 6$ & I $1 \cdot 9$ & - & $2 \cdot 3$ & $18 \cdot 5$ & $56 \cdot 3$ & $8 \cdot 4$ & - & - \\
\hline Rapeseed oil & - & - & - & - & - & - & - & $2 \cdot 8$ & $\operatorname{tr}$ & $\operatorname{tr}$ & $16 \cdot 2$ & 14.8 & $10 \cdot 1$ & $10 \cdot 2$ & 45.9 \\
\hline
\end{tabular}

tr, less than $I \%$.

* Number of carbon atoms and number of double bonds (Farquhar, Insull, Rosen, Stoffel \& Ahrens. 1959). 
in triolein. The major acid of Intralipid was linoleic acid, with important amounts of palmitic, oleic and linolenic acids. Rapeseed oil was rich in erucic acid with smaller amounts of palmitic, oleic, linoleic, linolenic and eicosenoic acids.

The major fatty acids of the egg phosphatides were palmitic and oleic, with smaller quantities of stearic and linoleic acids.

\section{Tolerance to infusions}

Infusion of tripalmitin or triisostearin was associated with a slight increase in respiration rate. During the infusion of tributyrin animals showed an elevated temperature, loss of balance and an increase in respiration rate: these signs appeared within $6 \mathrm{~h}$ of the commencement of the infusion but did not become more severe and the infusions were completed. Other materials were infused without signs of distress.

\section{Effects of infusions on blood composition}

Concentrations of plasma lipid fractions. Mean values for each sow for the concentrations of lipid fractions during the control and infusion periods are given in Table 2. In the majority of animals the concentration of plasma triglycerides increased in response to the infusion if the emulsions and the effect tended to be more pronounced with the infusions of longer-chain triglycerides. There was no clear pattern of change in the concentrations of plasma lipid fractions other than the triglycerides.

Table 2. Effect of intravenously infused triglycerides on the concentration of blood plasma lipids in the sow

\begin{tabular}{|c|c|c|c|c|c|c|c|c|}
\hline \multirow{2}{*}{$\begin{array}{c}\text { Triglyceride } \\
\text { infused }\end{array}$} & \multicolumn{2}{|c|}{$\begin{array}{l}\text { Cholesterol ester* } \\
(\mathrm{mg} / \mathrm{r} \circ 0 \mathrm{ml})\end{array}$} & \multicolumn{2}{|c|}{$\begin{array}{c}\begin{array}{c}\text { Free cholesterol } \\
(\mathrm{mg} / \mathrm{I} \text { oo } \mathrm{ml})\end{array} \\
.\end{array}$} & \multicolumn{2}{|c|}{$\begin{array}{l}\text { Phospholipid } \\
\text { (mg/roo ml) }\end{array}$} & \multicolumn{2}{|c|}{$\begin{array}{l}\text { Triglyceridet } \\
(\mathrm{mg} / \mathrm{r} 00 \mathrm{ml})\end{array}$} \\
\hline & Control & Infusion & Control & Infusion & Control & Infusion & Control & Infusion \\
\hline Tributyrin & $\begin{array}{l}145 \\
\times 87\end{array}$ & $\begin{array}{l}\text { I } 28 \\
\text { I } 55\end{array}$ & $\begin{array}{l}26 \\
40\end{array}$ & $\begin{array}{l}25 \\
33\end{array}$ & $\begin{array}{r}84 \\
\times 87\end{array}$ & $\begin{array}{r}74 \\
\times 35\end{array}$ & $\begin{array}{l}17 \\
46\end{array}$ & $\begin{array}{l}23 \\
60\end{array}$ \\
\hline Tricaprylin & $\begin{array}{r}71 \\
174\end{array}$ & $\begin{array}{l}\text { I } 14 \\
\text { I } 78\end{array}$ & $\begin{array}{l}36 \\
32\end{array}$ & $\begin{array}{l}45 \\
32\end{array}$ & $\begin{array}{r}89 \\
161\end{array}$ & $\begin{array}{l}139 \\
\text { I } 46\end{array}$ & $\begin{array}{l}46 \\
30\end{array}$ & $\begin{array}{l}34 \\
33\end{array}$ \\
\hline Tripelargonin & $\begin{array}{r}\text { roI } \\
86\end{array}$ & $\begin{array}{l}90 \\
79\end{array}$ & $\begin{array}{l}21 \\
16\end{array}$ & $\begin{array}{l}19 \\
17\end{array}$ & $\begin{array}{r}105 \\
94\end{array}$ & $\begin{array}{l}89 \\
94\end{array}$ & $\begin{array}{l}32 \\
28\end{array}$ & $\begin{array}{l}38 \\
38\end{array}$ \\
\hline Tricaprin & $\begin{array}{l}\text { I76 } \\
\times 69\end{array}$ & $\begin{array}{l}195 \\
191\end{array}$ & $\begin{array}{l}39 \\
32\end{array}$ & $\begin{array}{l}37 \\
34\end{array}$ & $\begin{array}{l}160 \\
149\end{array}$ & $\begin{array}{l}169 \\
173\end{array}$ & $\begin{array}{l}36 \\
50\end{array}$ & $\begin{array}{l}42 \\
57\end{array}$ \\
\hline Trilaurin & $\begin{array}{l}190 \\
130\end{array}$ & $\begin{array}{l}218 \\
105\end{array}$ & $\begin{array}{l}46 \\
23\end{array}$ & $\begin{array}{l}50 \\
2 I\end{array}$ & $\begin{array}{r}215 \\
93\end{array}$ & $\begin{array}{r}231 \\
74\end{array}$ & $\begin{array}{l}55 \\
27\end{array}$ & $\begin{array}{l}70 \\
33\end{array}$ \\
\hline Trimyristin & $\begin{array}{l}\text { I } 15 \\
140\end{array}$ & $\begin{array}{l}\text { I } 33 \\
\text { I } 36\end{array}$ & $\begin{array}{l}23 \\
23\end{array}$ & $\begin{array}{l}23 \\
22\end{array}$ & $\begin{array}{r}98 \\
104\end{array}$ & $\begin{array}{l}86 \\
64\end{array}$ & $\begin{array}{l}49 \\
26\end{array}$ & $\begin{array}{l}43 \\
35\end{array}$ \\
\hline Tripalmitin & $\begin{array}{l}125 \\
\times 46\end{array}$ & $\begin{array}{l}\text { I } 31 \\
\text { I } 49\end{array}$ & $\begin{array}{l}23 \\
23\end{array}$ & $\begin{array}{l}24 \\
23\end{array}$ & $\begin{array}{l}131 \\
\times 56\end{array}$ & $\begin{array}{l}151 \\
160\end{array}$ & $\begin{array}{l}20 \\
2 I\end{array}$ & $\begin{array}{l}25 \\
25\end{array}$ \\
\hline Triisostearin & $x_{1} 3$ & xI7 & 26 & 24 & $\times 34$ & 140 & 29 & $3 x$ \\
\hline Triolein & $\begin{array}{l}\text { x } 47 \\
\text { I } 94\end{array}$ & $\begin{array}{l}190 \\
163\end{array}$ & $\begin{array}{l}26 \\
36\end{array}$ & $\begin{array}{l}24 \\
29\end{array}$ & $\begin{array}{l}102 \\
134\end{array}$ & $\begin{array}{l}115 \\
146\end{array}$ & $\begin{array}{l}20 \\
29\end{array}$ & $\begin{array}{l}41 \\
59\end{array}$ \\
\hline Intralipid & $\begin{array}{l}x 66 \\
x 46\end{array}$ & $\begin{array}{l}\text { I3I } \\
\text { I } 25\end{array}$ & $\begin{array}{l}36 \\
31\end{array}$ & $\begin{array}{l}37 \\
21\end{array}$ & $\begin{array}{l}156 \\
128\end{array}$ & $\begin{array}{l}\text { I } 84 \\
\text { IOI }\end{array}$ & $\begin{array}{l}4 I \\
39\end{array}$ & $\begin{array}{l}54 \\
54\end{array}$ \\
\hline Rapeseed oil & $\begin{array}{l}\text { I I } 4 \\
\text { I } 48\end{array}$ & $\begin{array}{l}109 \\
122\end{array}$ & $\begin{array}{l}22 \\
31\end{array}$ & $\begin{array}{l}27 \\
22\end{array}$ & $\begin{array}{r}97 \\
161\end{array}$ & $\begin{array}{r}89 \\
\text { I 10 }\end{array}$ & $\begin{array}{l}35 \\
29\end{array}$ & $\begin{array}{l}28 \\
5 I\end{array}$ \\
\hline
\end{tabular}

*. Expressed as cholesterol oleate. $\dagger$ Expressed as triolein. 
Vol. 24

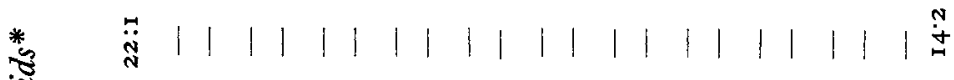

过

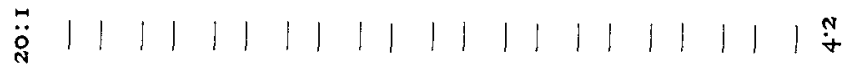

3

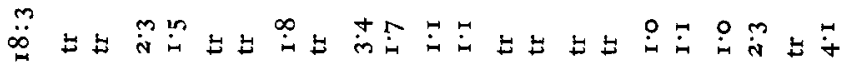

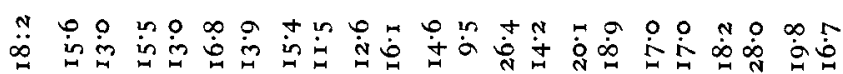

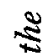

के

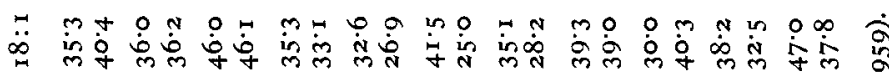

O

要

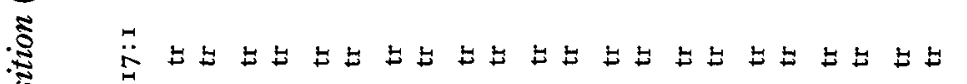

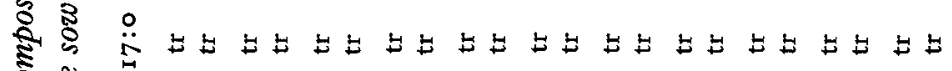
:

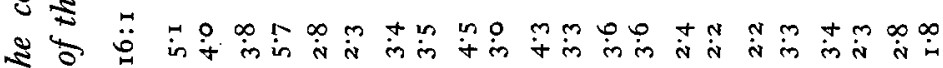

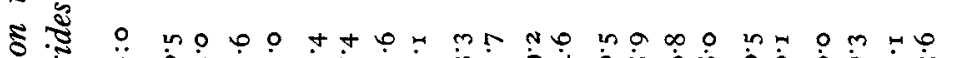

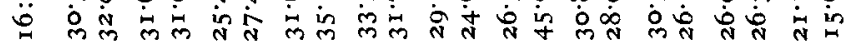

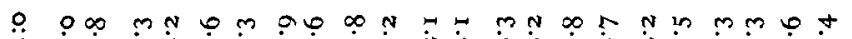

If

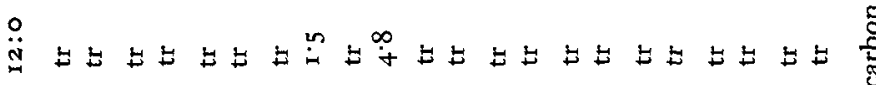

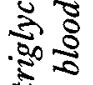

i

호

$\stackrel{\circ}{0}=|1||| \vec{i}|1||t z= \pm| 1|1| 1 \mid$

$\stackrel{\circ}{a}|1| 1 \mid \stackrel{\circ}{0}$

$i_{i}|1| 1$

$\infty$

$\ddot{\infty}|||\geq||||||||||||||||| \mid$

$\ddot{\circ}|1| 1|1| 1|1| 1|1| 1|1| 1 \mid 1)$ $\stackrel{\circ}{q}$

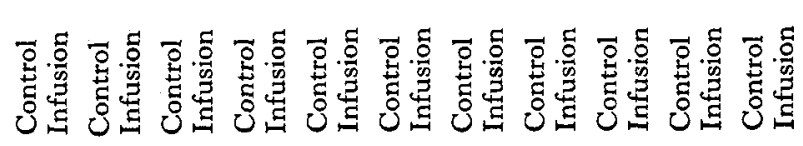

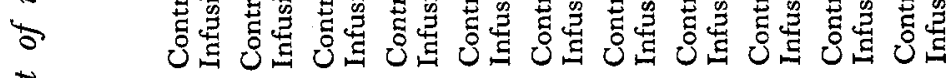

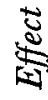

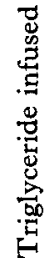

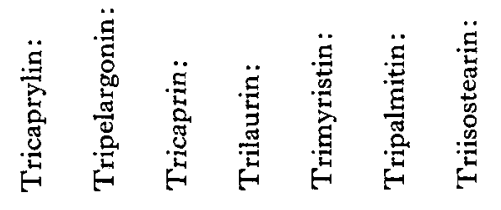

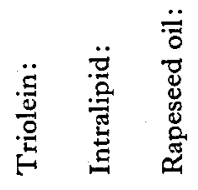


$\frac{2}{3}$

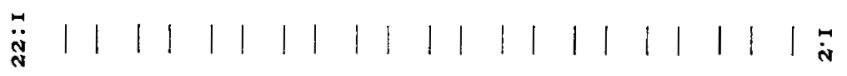

$\ddot{\ddot{o}}|1| 1|1| 1|1| 1|1| 1|1| 1 \mid 1 \%$

壳

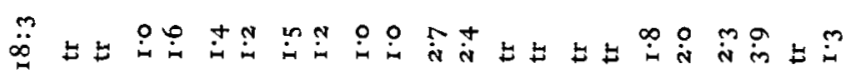

$\frac{5}{5}$

엉

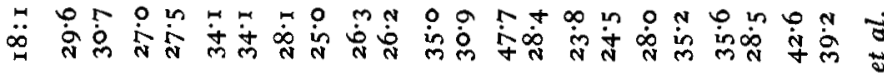

20
8
$\frac{8}{9}$

:

ฐ

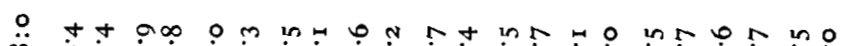

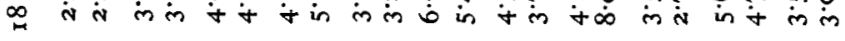

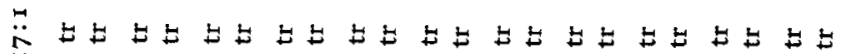

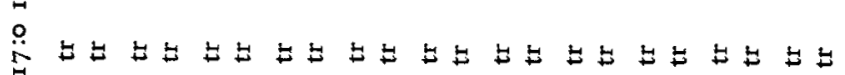

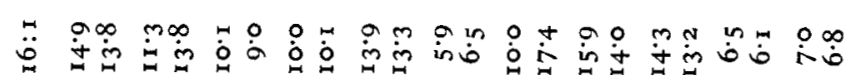

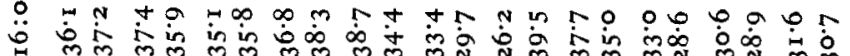
0 O

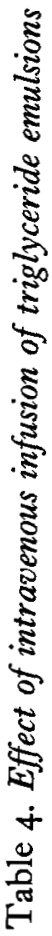

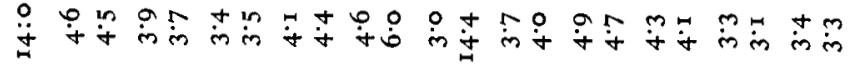

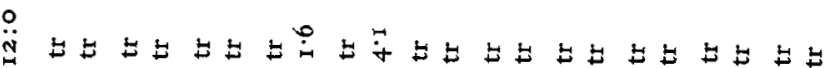

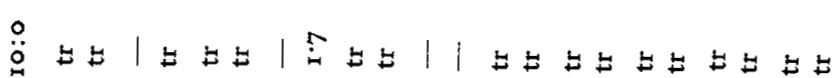

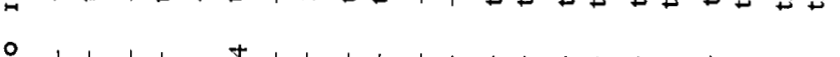

$\stackrel{\circ}{a}|1| 1 \pm \stackrel{+}{\dot{m}}$

$\stackrel{\circ}{\infty}|1| \stackrel{0}{i}$

$\ddot{0}$

$\stackrel{\circ}{\ddot{f}}$ |

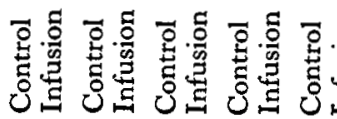

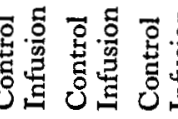

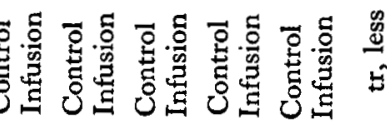
总总

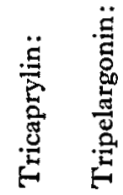

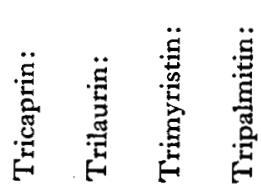

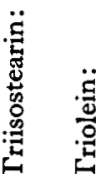

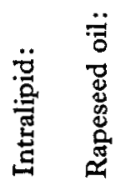


Fatty acid composition of plasma lipid fractions. The effect of intravenous infusion of the triglycerides on the composition of plasma triglycerides is shown in Table 3 . Values are a mean for two sows, with the exception of the results for triisostearin which was infused in one sow only. The shorter-chain fatty acids, butyric to capric, are usually absent from the plasma triglycerides of the sow, and lauric acid is present only in trace amounts. Butyric acid was not detected in the plasma triglycerides during the infusion of tributyrin and caprylic, and pelargonic acids were detected only at the higher rates of infusion of the corresponding triglycerides. With the other infused materials the major acid present increased, as a proportion of the fatty acids of the plasma triglycerides, and for the saturated acids the effect was more marked for the longer-chain acids up to and including palmitic acid. The response in $\mathrm{C}_{18}$ saturated acids to the infusion of triisostearin which, together with tripalmitin, was infused at one half the concentration of the other triglycerides, was much less than that in palmitic acid during the infusion of tripalmitin, as was the response in oleic acid during the infusion of triolein.

The contents of linoleic and linolenic acids were both increased during the infusion of Intralipid and of eicosenoic and erucic acids during the infusion of rapeseed oil. Allowing for the lower contents of these acids in the infused materials, the order of response was similar to that for myristic and palmitic acids.

The contents in the plasma triglycerides of acids absent from or present only in small amounts in the infused materials usually were reduced and roughly in proportion to the increase in the content of the major infused acid. An exeption was that infusion of short-chain triglycerides produced changes in the content of linoleic acid: infusion of triglycerides up to and including tricaprin were associated with a decrease, infusion of trilaurin with an increase. Compensatory changes were mainly in other $\mathrm{C}_{18}$ acids but during the infusion of tricaprin the content of palmitic acid was increased.

The changes in the composition of the plasma free fatty acids in response to the infusion of triglycerides followed a pattern similar to that observed for the plasma triglycerides but the effects were much less marked. There were, also, small increases in the contents of myristic, palmitic, oleic and linoleic acids in the plasma phospholipids during the infusion of triglycerides rich in those acids. The composition of the fatty acids of the cholesterol esters was not affected, except during the infusion of trimyristin when there was a small increase in the content of myristic acid.

\section{Fatty acid composition of milk fat}

Mean changes in the fatty acid composition of milk fat are given in Table 4. With one or two exceptions, changes were similar to those observed in the plasma triglycerides. The major acid of the infusate was not detected in milk fat during the infusion of tributyrin or of tricaprylin or tripelargonin at the lower rate of infusion. Infusion of tricaprylin and tripelargonin at the higher rate and of tricaprin resulted in the appearance of the corresponding acids in milk fat. The major acid of other infused materials was invariably increased in milk fat, but, relative to the changes in the composition of the plasma triglycerides, the responses in myristic and palmitic acids were less than for the other saturated acids. Increase in linoleic and linolenic acids in 
276 R. C. Witter, J. Spincer, J. A. F. Rook and K. G. Towers 1970

response to the infusion of Intralipid and of oleic acid to the infusion of triolein were in proportion to the increases in the plasma triglycerides, but during the infusion of rapeseed oil the increases in milk fat of eicosenoic and erucic acids were slight.

Complementary changes in other acids reflected closely the changes in plasma triglycerides, with three exceptions. The reduction in the content of oleic acid and the increase in that of linoleic acid in plasma triglycerides observed during the infusion of trilaurin did not produce corresponding changes in the composition of milk fat. The infusion of tripalmitin increased the content in milk fat not only of palmitic acid but also of palmitoleic acid and the limited transfer of eicosenoic and erucic acids to milk fat during the infusion of rapeseed oil resulted in much smaller complementary changes in other fatty acids than was observed for the plasma triglycerides.

\section{DISCUSSION}

The transport forms of triglycerides of the plasma are the chylomicra and the lipoprotein complexes (Senior, 1964). The infusion of synthetic triglycerides emulsified with egg phosphatides thus cannot be considered wholly physiological. However, liquid emulsions are rapidly cleared in vitro by heparinized plasma (Hollett, Cole \& Meng, 1953): combination of exogenous fat particles with plasma lipoproteins is a prerequisite and this association occurs readily (Korn, 1955). Moreover, in dog and man there are similar patterns of clearance from the plasma of chylomicra and of artificial emulsions of soya-bean oil (Hallberg, I965) and in the rat there is no distinction between chylomicra and artificial emulsions of triglycerides in their uptake and utilization by the mammary gland (Schoefl \& French, I968).

The signs of distress observed during the infusion of tributyrin have been reported previously in the mouse and rat (Wretlind, 1957, 1964) and in the cow (Storry, Tuckley \& Hall, 1969). They appear to be due to a toxic effect of tributyrin itself and not to the physical form of the infused material. The increase in respiration rate observed during the infusion of tripalmitin and triisostearin may be due to the high melting-points of these triglycerides and to a resulting partial occlusion of the blood capillaries of the lungs. Kauste (1958) induced fever in the rabbit by the infusion of an emulsion of rapeseed oil but no effect was observed in the sow, nor was the initial rise in body temperature noted by Storry, Tuckley \& Hall (1969) in cows receiving an infusion of trimyristin.

The absence of any change or the slight change in the composition of plasma and milk triglycerides, and of other plasma lipid fractions, during the infusion of shortchain triglycerides, observations which are in line with those of Storry, Tuckley \& Hall (1969) in the cow suggests that there was a rapid catabolism of those materials. Short-chain fatty acids are absorbed from the digestive tract primarily as free fatty acids into the portal vein and are not, as are the longer-chain fatty acids, resynthesized into triglycerides in the intestinal epithelium (Senior, 1964). They are transported to the liver as plasma albumin complexes where they appear to be rapidly metabolized: oxidation rather than chain elongation occurs (Métais \& Bach, 1967; Zurier, Campbell, Hashim \& Van Itallie, 1967; Scheig \& Klatskin, 1968). Short-chain fatty acids are 
not, therefore, normal constituents of the plasma triglycerides, but it appears that even when present they may be rapidly catabolized, presumably in the liver.

The relationship between the change in plasma triglyceride and in milk fat of the content of the major infused acid is shown in Fig. r. With the exception of erucic and eicosenoic acids, and possibly also of myristic acid, changes in milk fat reflect closely changes in the plasma triglycerides. Though fatty acids up to and including lauric acid are normally absent from or present only in very small amounts in the milk fat of the sow, there nevertheless appears to be a ready transfer of short-chain fatty acids

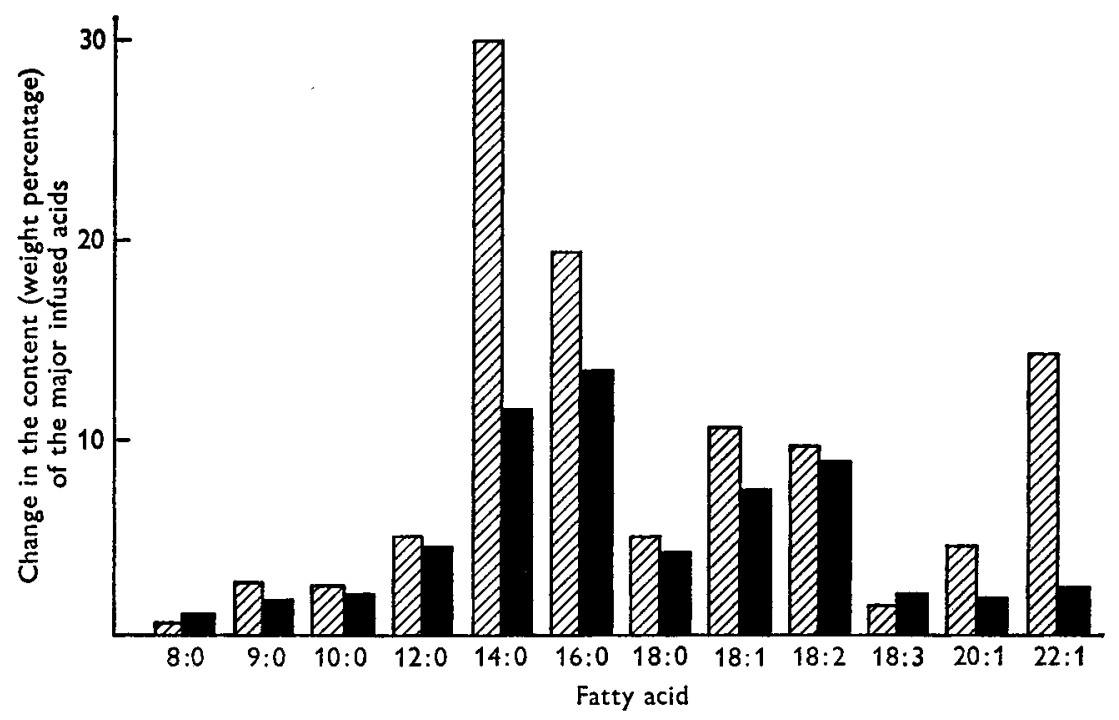

Fig. 1. Relationship in the sow between the change in plasma triglycerides and in milk fat of the content of major infused acids. $\mathbb{Z}$, plasma triglyceride fatty acids; $\mathbf{Q}$, milk fat fatty acids.

of chain length of $\mathrm{C}_{8}$ or above when they are present in plasma triglycerides. In contrast to the short-chain acids, a considerable synthesis de novo of myristic and palmitic acids occurs within the sow mammary gland (Linzell et al. 1969) but the present results confirm that there is additionally an uptake of those acids from the plasma triglycerides and that the uptake is sensitive to the circulating level. During the infusion of tripalmitin there was also an increase in the content in milk fat of palmitoleic acid, an acid present in much higher concentration in the milk fat of the sow than in that of the cow (Rook \& Witter, 1968). Bickerstaffe \& Annison (r968) have demonstrated the presence of a desaturase system in sow mammary tissue which, on the basis of the present results, must show a high activity towards palmitic acid.

As in other species, in the sow fatty acids in milk fat of greater chain length than $\mathrm{C}_{16}$ are derived largely from fatty acids of the plasma triglycerides (Linzell et al. 1969). The present results support a direct transfer of isostearic, oleic, linoleic, linolenic, erucic and eicosenoic acids and a limited desaturation of $\mathrm{C}_{18}$ saturated acids to oleic acid. The changes in milk fat in eicosenoic acid and, more especially, erucic acid relative to the changes in the plasma triglycerides are proportionately much less than for other acids. There is evidence in the cow of a barrier to their uptake by the mam- 
mary gland (Beitz \& Davis, 1964; Storry, Hall, Tuckley \& Millard, 1969) and erucic acid has been shown to be poorly absorbed from the intestine (Deuel, Hallman \& Leonard, I940; Thomasson, 1956).

Complementary changes in milk fat of acids other than major acids of the infused materials, with the exception of that in palmitoleic acid during the infusion of tripalmitin, reflected mainly the changes in the composition of the plasma triglycerides. There was no evidence that infusion of the emulsions specifically depressed oleic acid content, nor of chain elongation of short-chain and intermediate-chain fatty acids within the mammary gland, as was observed by Storry, Tuckley \& Hall (I 969) in the cow.

We thank Mr T. G. Boaz and Mr A. F. Calder for the supply of animals and provision of facilities at Leeds University Farm, and Mr J. B. Hopwood and Mrs M. Davies for skilled technical assistance. The work was supported financially by a grant from the Pig Industry Development Authority, to whom we express our thanks. One of us (J. S.) is in receipt of a Pig Industry Development Authority Postgraduate scholarship. We are grateful to Messrs Price's Chemicals, Wirral, Cheshire, for gifts of tripalmitin and isostearic acid, and Messrs Paines and Byrne, Greenford, Middlesex, for a gift of Intralipid.

\section{REFERENCES}

Amenta, J. S. (1964). F. Lipid. Res. 5, 270.

Beitz, D. C. \& Davis, C. L. (1964). F. Dairy Sci. 47, 1213.

Bickerstaffe, R. \& Annison, E. F. (1968). Biochem. $\mathcal{~}$. 108, 47 P.

Deuel, H. J. Jr, Hallman, L. \& Leonard, A. (1940). F. Nutr. 20, 215.

Farquhar, J. W., Insull, W. Jr, Rosen, P., Stoffel, W. \& Ahrens, E. H. Jr (1959). Nutr. Rev. I7, no. 8, Part 2, suppl.

Freeman, C. P. \& West, D. (1966). F. Lipid Res. 7, 324.

Folch, J., Lees, M. \& Stanley, G. H. S. (1957). F. biol. Chem. 226, 497.

Hallberg, D. (1965). Acta physiol. scand. 65, 153 .

Hollett, C., Cole, W. E. \& Meng, H. C. (1953). Fedn Proc. Fedn Am. Socs exp. Biol. 12, 70.

Kauste, O. (1958). Annls Paediat. Fenn. 4, suppl. no. то.

Korn, E. D. (1955). \%. biol. Chem. 2r5, I5.

Linzell, J. L., Mepham, T. B., Annison, E. F. \& West, C. E. (1969). Br. F. Nutr. 23, 319.

Métais, P. \& Bach, A. (1967). Cahiers Nutrition Diététique 2, 77.

Metcalfe, A. D. \& Schmitz, A. A. (196r). Analyt. Chem. 33, 363.

Rook, J. A. F. \& Witter, R. C. (1968). Proc. Nutr. Soc. 27, 71.

Scheig, R. \& Klatskin, G. (1968). F. Am. Oil Chem. Soc. 45, 3 I.

Schoefl, G. I. \& French, J. E. (1968). Proc. R. Soc. B 169, I53.

Schuberth, O. \& Wretlind, A. (196I). Acta chir. scand. suppl. no. 278.

Senior, J. R. (1964). F. Lipid Res. 5, 495.

Singleton, W. S., Gray, M. S., Brown, M. L. \& White, J. L. (I965). F. Am. Oil Chem. Soc. 42, 53. Spincer, J., Rook, J. A. F. \& Towers, K. G. (1969). Biochem. F. x11, 727.

Storry, J. E., Hall, A. J., Tuckley, N. \& Millard, D. (I969). Br. F. Nutr. 23, 173.

Storry, J. E. \& Rook, J. A. F. (1964). Biochem. F. 91, 27 c.

Storry, J. E., Rook, J. A. F. \& Hall, A. J. (1967). Br. F. Nutr. 21, 425.

Storry, J. E., Tuckley, B. \& Hall, A. J. (1969). Br. F. Nutr. 23, I 57.

Thomasson, H. J. (1956). F. Nutr. 59, 343.

Tove, S. B. \& Mochrie, R. D. (1963). F. Dairy Sci. 46, 686.

Wretlind, A. (1957). Acta physiol. scand. 40, 338 .

Wretlind, A. (1964). Acta chir. scand. suppl. no. 325.

Zeringue, H. J., Brown, M. L. \& Singleton, W. S. (1964). F. Am. Oil Chem. Soc. 4r, 688.

Zurier, R. B., Campbell, R. G., Hashim, S. A. \& Van Itallie, T. B. (I967). Am. F. Physiol. 212, 291. 